\title{
Imprisonment for Debt: In the Military Tradition
}

Civilian criminal sanctions for indebtedness were for the most part repealed during the colonial era. Imprisonment for debt as a method of enforcing commercial obligations is now banned in every state. ${ }^{1}$ State law prohibitions vary in certain respects, but all forbid criminal sanctions against the honest but insolvent debtor.? Most statutes permit imprisonment only where fraud is involved in contract delinquency. ${ }^{3}$ In one very large jurisdiction, however, the sanctions for indebtedness remain. Under Article 134 of the Uniform Code of Military Justice (UCMJ), the general article for enlisted men, ${ }^{+}$it is a crime to fail, dishonorably, to pay a debt. This Note will examine

1. Forty-one states ban imprisonment for indebtedness by provisions in their constitutions, and nine have statutory prohibitions. The enactments present a vide spectrum from an absolute ban to a less stringent requirement that the debtor should be released by means of a poor debtor's oath so long as he has turned over his property to his creditors and does not plan to abscond from the jurisdiction. The constitutional provisions are: ALA. Const. art. I, § 20; ALAS. Const. art. I, § 17; ARIz. CoNst. art. II, \& 18; ARt. Const. art. II, § 16; CAL. CoNST. art. I, § 15; Colo. CoNST. art. II, § 12; FLA. CoNst., Decl. of Rights § 16; GA. Const. art. I, § 2-121; HAwAII CoNst. art. I, § 17; IDAHo CoNst. art. 1, § 15; ILL. Consr. art. II, § 12; IND. Const. art. I, § 22; IOWA Cosist. art. 1, § 19; Kan. Cosist., Bill of Rights § 16; KY. Const., Bill of Rights § 18; MID. Const. art. III, \$ 38; MIICH. Const. art. I, \& 21; MINN. Const. art. 1, § 12; MIISs. CoNst. art. III, § 50; MIo. Cosst. art. 1, § 11; MONT. Const. art. III, \& 12; NEB. CoNst. art. I, § 20; Nev. CoNst. art. I, \& 14; N.J. CoNst. art. I, I 13; N.M. CoNST. art. II, § 21; N.C. CoNST. art. I, § 28; N.D. CoNst. art. I, § 15; OHo CoNst. art. I, § 15; ORLA. CoNST. art. II, § 13; ORE. CoNst. art. I, § 19; PA. CoNst. art. I, \$ I6; R.I. CoNST. art. I, § 11, S.C. CoNST. art. VI, \& 24; S.D. Const. art. I, § 15; TENN. Const. art. I, § 18; TEx. Const. art. I, § 18; UTAH Const. art. I, § 16; Vr. Const. ch. II, § 32; WASH. CoNst. art. I, § 17; WIS. Const. art. I, \& 16; W'ro. CoNst. art. I, \& 5. Statutory provisions include: CoNN. GEN. STAT. \$ 18.56 (1958); 10 DEL. CODE ANN. \$ 5052 (1953); LA. REV. STAT. \$ 9:2664 (1964); 14 ME. Rev. STAT. \$ \$605 (1964); ANwotated LAWS OF MAss. c 224 \& 6 (1955); N.H. Rev. STAT. 533:13 (1955); N.Y. DentoR aNo Crentron LAW $\S 132$ (McKinney 1940); CODE OF VA. \$ 8-567 (1950); and W. VA. CODE $\S 38-5-5$ (1960).

The Supreme Court has upheld the state bans on imprisonment for debt, holding that they do not violate U. S. CoNST. art. 1, § 10, which prohibits any law impairing the obligation of contracts. Penniman's Case, 103 U.S. 714 (1880); Mason v. Haile, $\mathbf{2}$ U.S. (12 Wheat.) 370 (1827); Sturges v. Crowninshield, 17 U.S. (4 Wheat.) 122 (1819).

2. See, e.g., R.I. CoNst. art. 1, § 11:

The person of the debtor, when there is not a strong presumption of fraud, ought not to be continued in prison, after he shall have delivered up his property for the benefit of his creditors, in such manner as shall be prescribed by law;

and Mo. Const. art. 1, § II:

[N]o person shall be imprisoned for debt, except for nonpayment of fines and penalties imposed by law.

3. See, e.g., People v. LaMothe, 331 III. 351, 163 N.E. 6 (1928). One state has banned imprisonment even when fraud is present. Carr v. State, 106 Ala. 35, 17 50. 350 (I894).

4. 10 US.C. $\$ 934$ (1970). The Uniform Code of Mfilitary Justice is embodied in 10 U.S.C. $\$ \$ 801-940$ (1970). (To convert the U.S.C. reference to an article of the UC.IJ, subtract 800; thus 10 U.S.C. $\$ 934$ (1970) is Article 134). This Note is concerned almost entirely with the indebtedness specification under Article 134, rather than the similar provision in Article 133, the general article for officers (see note $12 \mathrm{infra}$ ). The effect of discrediting conduct by officers, who must be able to command the respeet of their sub. ordinates, may present a different set of considerations from those pertaining to Article 194 prosecutions. 
the attempted military, economic and legal justifications for this criminal sanction. It will argue that the military punishment for delinquent indebtedness traverses the intended boundaries of the UCMJ, serves no vital military purpose, requires the services to play an inappropriate and indefensible role in the collection process, and runs afoul of the jurisdictional restrictions placed on military tribunals by the Supreme Court in O'Callahan v. Parker. ${ }^{5}$

\section{Prosecutions under Article 134}

Article 134 prohibits any act that might bring discredit to the military or undermine military order and discipline:

Though not specifically mentioned in this chapter, all disorders and neglects to the prejudice of good order and discipline in the armed forces, all conduct of a nature to bring discredit upon the armed forces, and crimes and offenses not capital, of which persons in this chapter may be guilty, shall be taken cognizance by a general, special or summary court-martial, according to the nature and the degree of the offense and shall be punished at the discretion of the court. 6

Article 134 does not itself mention anything about failure to pay a debt. The accusation in any military trial is composed of both a "charge," which is the relevant article of the UCMJ,7 and a "specification." The specification, a list of the factual allegations which sup. port the change, is derived from the Manual for Courts-Martial. Prosecution for failure to pay indebtedness under Article 134 is authorized by Specification 138 of the Manual. ${ }^{8}$ If convicted, a serviceman can be

5. 395 U.S. 258 (1969).

6. 10 U.S.C. $\$ 934$ (1970).

For critical analysis of the general articles, see Hagan, The General Article-Elemental Confusion, 10 MiLitary L. REv. 63 (1960); Nelson, Conduct Expected of An Officer and A Gentleman: Ambiguity, 12 U.S.A.F. JAG L. REv. 124 (1970); Nichols, The Devil's Article, 22 Miltiary L. REv. 111 (1963); Wiener, Are the General Military Articles Unconstitt. tionally I'ague?, 54 A.B.A.J. 357 (1968); Note, 34 NEB. L. REv. 518 (1955); Notc, The Discredit Clause of the UCMJ: Unrestricted Anachronism, 18 U.C.L.A. L. REV. 821 (1971).

7. Manual For Courts-Martial United States $\$ 24$ (rev. ed. 1969).

8. Specification 138 reads:

In that - , being indebted to - in the sum of $\$-$ for - which amount became due and payable (on) (about) (on or about) $\longrightarrow$, did, (at) (on board) from $-19-$ to $-19-$, wrongfully and dishonorably to pay said debt.

Id. at App. 6c.

A wide spectrum of crimes are punishable under Article 134. See, e.g., United States v. Keaton, 19 U.S.C.M.A. 64, 41 C.M.R. 64 (1969) (assault with intent to kill); United States v. Marshall, 18 U.S.C.M.A. 426, 40 C.M.R. 138 (1969) (bribery and graft); United States v. Rener, 17 U.S.C.M.A. 65, 37 C.M.R. 329 (1967) (unlawful colabitation); Unitcd States v. Levy, 39 C.M.R. 672 (ACMR 1968) (making disloyal statements to promote distffection among servicemen). 
punished by up to six months imprisonment, forfeiture of all pay and allowances for six months, reduction in rank to the lowest grade, and a bad conduct discharge. ${ }^{9}$ In evaluating the military crime of indebtedness, one must examine the types of acts for which indebtedness prosecution is undertaken, the military discipline rationale which has been employed to justify prosecution, and the merits of using a military sanction as a civilian creditor collection device.

\section{A. Three Categories of Prosecutions}

Article 134 prosecutions for dishonorable failure to pay a just debt fall into three categories. ${ }^{10}$ The first involves transactions where the failure to pay has a potentially detrimental effect upon military discipline. A typical example is a loan between two servicemen. In United States $v$. True, ${ }^{11}$ for instance, an Army captain borrowed \$245 from a lieutenant under his command and ignored a later request for repayment. The officer was prosecuted and convicted under Article 133, the general article for officers. ${ }^{12}$ In affirming, an Army Board of Review stressed the traditional military disapproval of monetary transactions between servicemen of different rank. The Board saw a threat to military discipline and morale because an officer had used his rank to secure a private gain from his subordinate, and because failure to repay would destroy the trust servicemen must have in each other to act effectively as a unit. ${ }^{13}$

The second category involves off-base consumer transactions in which the serviceman commits the kind of fraud punishable under state law. While state laws vary, the crime of fraud has at least two overlapping, indispensable characteristics. The act must include deceit, evasion, or misrepresentation, directed toward and relied upon by one to whom

9. Manual for Courts-Martial Untred States q 127c (rev. ed. 1909).

10. The categories delineated in this Note have been devcloped solely as an aid to analysis. Neither the Court of Military Appeals nor military Boards of Review have ever proposed or explicitly outlined the categories employed here.

I1. 10 C.M.R. 328 (ACMR 1953). The Courts of Military Review, which were enlled Boards of Review prior to a 1968 amendment to the UCMIJ, are intermediate appellate courts. Appeals from these courts can be taken to the Court of Mfilitary Appeals, a threemember court with civilian judges. For a description of the functions of these tribunals, see 10 U.S.C. $\S 866(1970)$, and I0 U.S.C. $\S 867$ (1970).

12. 10 U.S.C. \& $939(1970)$ :

Any commissioned officer, cadet, or midshipman, who is convicted of conduct un-

becoming an officer and a gentleman shall be punished as a court-martial may direct. The provision for an officer's dishonorable failure to pay a debt is authorized by Specification 124, Manual for Courts-Martial United States (rev. ed. 1969).

13. 10 C.M.R. at 332. See also United States v. Conway, 11 C.M.R. 625 (NCMIR 1953) (officer using his status to borrow from an enlisted man). 
the defendant owes a duty, ${ }^{14}$ and the perpetrator must have scienter ${ }^{15}$ A series of court-martial prosecutions under the failure to pay indebtedness provision has involved instances of fraud. In United States $v$. Blount, ${ }^{16}$ the military debtor made purchases with bad checks. Confronted with his worthless checks, the delinquent soldier pledged to his creditor that he would make immediate payment, but continued to evade the obligation. An Army Board of Review affirmed an Article 134 conviction, finding that the defendant had no intention to pay the debt when he made his pledge. Since the promise induced the creditor to forego immediate legal action, fraud was present. In United States $v$. DeLancey, ${ }^{17}$ an airman was accused of nine counts of dishonorable failure to pay in connection with taxi cab fares. The serviceman left at the end of each ride without paying, never using the same cab twice. The court decided that the scheme was a fraudulent attempt to avoid the fare, since business custom required immediate payment. ${ }^{18}$ Here, as in Blount, the court looked to the debtor's dealings with his creditor to establish culpability.

In the third category of prosecutions are cases in which neither fraud nor a direct concern for military discipline exists. The Court of Military Appeals has upheld convictions in these cases on the principle that the serviceman evinced dishonor in failing to meet his obligations. The factual situations in which dishonor has been found are extremely diverse and correspond to nothing in the civilian law of misrepresentation. Although dishonor within the meaning of Article 134 cannot be found either in simple non-payment or in negligently contracting too many financial obligations, ${ }^{10}$ the prosecution need not prove fraud. In fact, the evidence used to establish dishonor often ignores the deal. ings between the debtor and creditor, which are crucial to civilian fraud.

An example may be found in the use of gratuitous statements made to third parties to show dishonor. In United States $v$. Bonar, ${ }^{20}$ the de-

14. See generally 37 C.J.S. Fraud \& 1 (1943); Eliason v. Willburn, 335 I1l. 352, 167 N.E. 101 (1929), aff'd, 281 U.S. 457 (1930).

15. See C. W. Denning \&: Co. v. Suncrest Lumber Co., 51 F.2d 945 (4th Cir. 1931).

16. 5 C.M.R. 297 (ACMR 1952).

17. 34 C.M.R. 845 (AFCMR 1964).

18. Id. at 848 .

19. United States y. Kirksey, 6 U.S.C.M.A. 556, 20 G.M.R. 272 (1955). See also p. 1688 infra. For sources discussing the constitutional issues raised by the vagueness of the general articles, see note 6 supra.

20. 40 C.M.R. 482 (ACMR 1969). The Army has instructed its commanders to play an active role in indebtedness counseling. See p. 1686 and note 34 infra. 
fendant had been counseled on three occcasions by his commanding officer to pay a delinquent bill. The soldier never made any representations to, nor had any contacts with, his creditor. An Army Board of Review relied heavily on the defendant's discussions with his commanding officer in finding him criminally liable.

On one occasion appellant stated that he would "take care of it." His failure to do so indicates the existence of gross indifference, if not bad faith, and warrants the conclusion that his conduct was, under the circumstances, dishonorable..$^{21}$

A second case illustrates graphically that dishonor is not necessarily equated with fraud. In United States $v$. Swanson,, 2 a serviceman was discharged in bankruptcy. The referee made no finding of fraud or misrepresentation. ${ }^{23}$ Nevertheless, in a subsequent court martial, the serviceman was convicted for dishonorable failure to pay the discharged debt. An Air Force Board of Review affirmed, holding that the referee's examination into the creditor-debtor relationship was not determinative in the criminal proceedings.

In only the second of the three categories, then, does the Article 134 standard coincide with that required for civilian prosecutions. In the first and third categories, the serviceman is being punished for an act for which no civilian criminal sanction exists. Of course, the mere fact that the substantive content of Article 134 debt prosecutions differs from the civilian norm is not, in itself, ground for disapproval. The specific goals of the military justice system make necessary many crimes, such as being absent without leave, ${ }^{24}$ which have no civilian counterparts. But even if some variance between military and criminal law is permissible, the question remains: is prosecution for dishonorable failure to pay a debt justifiable? In answering that question, attention must be focused on the purposes of the separate system of military justice.

21. Id. at 484. This fact situation points to a way in which simple indebtedness is converted into the punishable category of dishonorable failure to pay a dcbt. Bul $c f . p$. 1682 supra. A unit commander often confronts the debtor with the creditor's letter of complaint and explains the possible use of Article 134 to punish dishonorable indebtedness. Then the commander asks the debtor what steps he intends to take to pay the creditor. Any attempt by the debtor to mollify his military superior with a promise to take care of the debt can become the factual basis of the dishonor if the serviceman then fails to pay.

22. 25 C.M.R. 832 (AFCMR 1957).

23. See 11 U.S.C. \$ 35 (1970), which provides that fraudulent debts annot be discharged.

24. Article 86 UCMJ, 10 U.S.C. § 886 (1970). 


\section{B. The Military Discipline Rationale}

The UCMJ was enacted, as were previous Articles of War, pursuant to Congress' power 'to make Rules for the Government and Regulition of the land and naval Forces." 25 The American mandate for a distinct order of military justice is not unique; the dichotomy between civilian and military systems of justice may be traced back to early Greek and Roman legal systems. ${ }^{26}$ Although American systems of military law have varied through the years, there has been a single underlying purpose for each-to maintain discipline in the armed forces. As a nineteenth century commentator argued:

If a national army be established, it is indispensably requisite that order and discipline should be established. To effect this, it is necessary that the duties of the military be defined and their performance enforced, under appropriate penalties, by tribunals appointed for that purpose. For this reason, rules and articles of war are ever found to accompany an army. ${ }^{27}$

The Congressional history of the UCMJ indicates that its drafters conceived the military code as a vehicle for enforcing and furthering discipline in the armed forces. This philosophy manifested itself in both the substantive and procedural aspects of the code. ${ }^{28}$

But even given the essential relation of military law to discipline, it must still be asked whether Article 134 debt prosecutions are necessary to the proper maintenance of discipline in the armed services.

As to offenses in the first category, where there is a potentially detrimental effect on discipline, it is clear that the military has a possible interest in prosecution. The use of rank to obtain loans from subordin. ates or the refusal of one serviceman to repay another could affect the morale of the personnel involved and hamper their ability to act effectively as a unit. Yet even here the abuses could be reached through means other than imprisonment for debt. The military could provide, either through general regulations or unit orders, that intra-military loans are prohibited. ${ }^{29}$ Such a proscription might tend to eliminate one type of abuse-the use of rank to obtain a loan-more effectively than

25. U.S. CoNsT. art. $1, \S 8$, cl. 14.

26. See generally W. Winthrop, Military LAw 4-10 (1886).

27. J. O'Brien, A Treatise on the AmERican MiLitTary Laws 25 (1816).

28. See Hearings on S. 857 Before a Subcomm. of the Senate Comm. on Armed Services, 81st Cong., lst Sess. (1949).

29. Article 92 UCMJ, 10 U.S.C. $\$ 892$ (1970). The article authorizes disciplinary action for the violation of any lawful general order or regulation. 
the current sanction, since the superior who repays is now outside the ambit of Article 134.

It is still more difficult to see a persuasive argument based on military discipline for Article $134 \mathrm{debt}$ prosecutions in the last two categories. ${ }^{30}$ By definition, such transactions occur off-base, in non-combat situations, and involve only one serviceman, the debtor. In the second category, where criminal fraud is involved, it could be argued that the debtor's status as a "criminal" affects his ability to function as a serviceman. ${ }^{31}$ Even if this, or some other military discipline rationale is accepted, however, a criminal sanction rooted in the dishonorable failure to pay provision is unnecessary. Prosecutions could take place either in civilian courts or under the general provisions of Article 134, on the theory that acts criminal under state law are "discrediting." 32 As to offenses in the last category, where fraud is absent, no military justification in terms of discipline exists. The serviceman is not a criminal, he is merely a defaulting debtor. Indeed, where promises to unrelated third parties (e.g., unit commanders) are relied upon to find "dishonor," Article 134 is itself the cause of many offenses. Were it not for the Article 134 threat of prosecution, the initial conversation with the commanding officer might not occur and there might never be any gratuitous pledge of payment.

Thus, prosecution for the crime of dishonorable failure to pay a debt satisfies no legitimate demand of military discipline, and so exceeds the intended scope of the UCMJ. To the extent that intra-military transactions or real criminal conduct is involved, prosecution is possible through other UCMJ provisions or through general orders of the military services. Article 134 may reach some situations where prosecution from some quarter is warranted. But it often (particularly in its application to the third category of prosecutions) extends to cases that have no connection with the essential goal of military law-to maintain discipline.

\section{Prosecution as a Collection Device}

Can debt prosecutions, then, be defended as a device salutary for

30. See note 41 infra.

31. For example, military regulations require that convicted servicemen lose their security clearances, be removed from sensitive positions, and be ineligible for any favorable personnel action, such as promotion or transfer, for specific periods of time. Ansry REGUtation 600-31 (June 29, 1970).

32. See Manual for Courts-Martial United States f 213(c) (rev. ed. 1969), where it is suggested that acts constituting violations of state law's may constitute "discrediting" conduct under Article 134. See also Hagan, supra note 6, at 71. 
the creditors of military personnel? It is certainly true that economic rationales form a powerful, if unstated, basis for indebtedness prosecutions under Article 134. As one commentator noted:

Unfortunately, though, as many military lawyers will testify, $[\mathrm{A}] \mathrm{r}$ ticle 134 is sometimes used as a lever by overreaching finance companies or sellers to secure payment of unjust claims. Time and again a serviceman will be terrified into paying a claim because of a letter from his alleged creditor-often with a copy to the accused's commander-wherein he is informed that he is subject to prosecution under $[\mathrm{A}] \mathrm{rticle} 134 .{ }^{33}$

The U.S. Army, while expressing its inablity to compel payment of private debts, has in the past told its commanders to "give careful consideration to the public relations aspect involved in private indebtedness and financial obligations." 34 The military directs its officers to discuss private indebtedness with the serviceman concerned, reminding commanding officers of their possible recourse to criminal sanctions of Article 134. ${ }^{35}$ Indeed, the use of Article 134 as a creditor device has been indirectly recognized by military courts. ${ }^{36}$ Thus, in diverse ways, the military services become collection arms for private business.

Several commercial reasons have been advanced to justify this relationship. Major James E. Simon ${ }^{37}$ has argued that military personnel often are transient and depend upon their military status for commercial credit, and that the creditor's recourse to civil remedies is often frustrated because of servicemen's transfers. ${ }^{38}$ Another argument is that, at common law, the ban on garnishment of the sovereign effectively prohibits the garnishment of servicemen's pay. ${ }^{30}$ Moreover, the Soldiers' and Sailors' Civil Relief Act of $1940^{10}$ severely restricts the creditor's

33. Everett, Article 134, Uniform Code of Military Justice-A Study in Vagueness, 37 N. CAR. L. REv. 142, 147 (1959),

34. 24 Fed. Reg. 14 (1959), embodied in 32 C.F.R. \& 513.1(a) until 1971, when the quoted langauge was deleted. The new regulations are directed primarily to creditors rather than unit commanders, and explain the procedures for acquiring military assistance in contacting debtors.

35. 24 Fed. Reg. 14 (1959), embodied in 32 G.F.R. \$ 513.1(b) until 1971, when the changes referred to in note 34 stupra were enacted.

36. In United States v. Cummins, 9 U.S.C.M.A. 669, 26 C.M.R. 449 (1958), the Court of Military Appeals held that Article 134 proceedings cannot commence over the objection of the creditor. In short, the device is not self-starting; it proceeds only when someone seeks to collect a debt.

37. Simon, $A$ Survey of Worthless Check Offenses, 14 Military L. REv. 29 (1961).

38. The Army is, however, willing to notify creditors of a soldier's current location. See 32 C.F.R. § 513.1(c)(4) (1971).

39. See generally 78 CoNG. Rec. 2231 (1944) (remarks of Representative Michener); R. ShinN, A TREATISE ON THE AMERICAN LAw OF ATTACHMENT AND GARNisHMent \& 500 (1900).

40. 50 U.S.C. $\$ 510$ (1964). For a thorough discussion of the practical effect of the act, 8ce W. ANderson, IEgal Status of Soldiers and Sallors Under Civil Relief ACt (1941). 
opportunity to collect. This Act protects servicemen from the harassment of civil suits that they cannot defend properly due to military commitments. A serviceman can stay proceedings in a civil case as to both judgment and attachment. This stay remains in effect until he can return to prepare a defense, which in some cases may be possible only at the conclusion of his military duty.

These various facts undoubtedly complicate collection for the civilian creditor. ${ }^{41}$ But even if it is conceded that special difficulties are faced by the serviceman's creditors, a fundamental issue remainsnamely, whether the armed services should in effect operate as a collection agency. ${ }^{42}$ Punctual credit payments by servicemen certainly are not relevant to their ability to perform military duties. There are federal employees who share, at least, the protection from garnishment $t^{-13}$ and the characteristic of being transient, but do not face criminal sanctions. No one would suggest that all government employees should be subjected to criminal penalities for indebtedness, and servicemen should not be treated differently.

Moreover, even if some collection device were justifiable, use of the Article 134 indebtedness sanction would still be open to substantial criticism. In the first place, while threats of Article 134 prosecutions may have some initial force to compel payment, most of the collection value of Article 134 is lost once the creditor presses charges to begin the criminal process. Since Article 134 is a criminal charge, the trial is not aimed at reimbursing the creditor. It is the "dishonor," not the debt, that is relevant. Consequently, the prosecution cannot be terminated by the serviceman's satisfaction of the obligation. ${ }^{44}$ In-

41. Soldiers have historically enjoyed some immunity from civilian collection techniques. Rules AND ARTICles OF War, \& 10 (1775); Act of May 28, 1798, 1 ch. 47, \$ 14, 1 Stal. 560 , both reported in J. Callan, The Military Laws of the United States 53, 88 (1858). 42. The military services engage much more actively in debt collection than a civilian employer. For example, before a civilian employer an garnish the wages of an employee, the debtor must be afforded prior notice and a hearing. Sniadach v. Family Finance Corp., 395 U.S. 337 (1969). The military cooperation in locating servicemen for creditors, in counseling military debtors and in utilizing UCMIJ sanctions against the debtor often begin on a creditor's application without any hearing or other civil court proceeding. Moreover, the military plays a prominent role in punishing the serviccman-debtor for his commercial actions through the criminal sanctions of the general articles. A civilian employer is prohibited by federal statute from firing an emplojec whose wages are garnished once. 15 U.S.C. \$ 1681 (1971). Yet the military not only can prejudicially discharge the debtor, it can impose fines and penal confinement on the offender. The jurisdictional problems inherent in court-martial intervention into off-post commercial transactions will be considered more fully at pp. 1688-94 infra.

43. Congress has considered lifting the ban on garnishment of government cmplojees. During World War II administrative problems defeated a bill designed to permit garnishment of federal employees, excluding servicemen. Hearings on H.R. 2985 Before a Subcomm. of the Senate Comm. on the Judiciary, 78th Cong., 2d Sess. (1944). H.R. 1517, 92d Cong., Ist Sess. (1971), would permit garnishment of all federal emplojees, including cervicemen.

44. United States v. Journell, 18 C.M.R. 752 (AFCMR 1955). 
deed, even if the debt no longer exists, because, for example, it has been discharged in bankruptcy, the trial for failure to pay continues. ${ }^{45}$ Secondly, the criminal nature of Article 134 reduces not only the incentive but also the ability of the debtor to pay. Forfeitures resulting from a court martial are paid to the government. Imprisonment, reduction in rank, or prejudicial discharge seriously impair the capacity of a serviceman to satisfy his delinquent debt. The court martial provides spite value, but may insure that the creditor will never be paid.

If Article 134 prosecution is really designed to strip immunity from the serviceman in commercial transactions, there are more efficacious alternatives. Congress could repeal the safeguards implemented in the Soldiers' and Sailors' Civil Relief Act, or allow garnishment of servicemen's pay. ${ }^{46}$ These steps would aid creditors in collection, and make military personnel, as a group, better credit risks. Alternatively, the government could be made a co-signer of installment obligations of the military buyer. The services could be given authority to deduct money from the serviceman's pay in the event that the government was com. pelled to honor the obligation. Any of these systems or a combination of them would facilitate military credit and give more actual benefit to the creditor than Article 134. They would also terminate the awkward and improper role of the military services in the collection process. The criminal sanction is not only inappropriate here, it is unjustifiable.

\section{O'Callahan v. Parker and the Nature of Service Connection}

Apart from the considerations above, the validity of military sanctions for indebtedness must be seriously questioned in light of the Supreme Court's decision in O'Callahan v. Parker.47 In that case, an Army sergeant on authorized pass in Hawaii broke into a hotel room occupied by a young girl, assaulted her, and attempted to rape her. O'Callahan challenged his court-martial conviction in a habeas corpus action, successfully contending that the military lacked jurisdiction to try him for a crime committed off duty and off post.

45. United States v. Swanson, 25 C.M.R. 832 (AFCMR 1957).

46. See note 42 supra.

47. 395 U.S. 258 (1969).

There is a flood of comment about O'Callahan; see, e.g., Blumenfeld, Court-Martial Jurisdiction Over Civilian-Type Crimes, 10 AM. CrIM. L. REv. 51 (1971); Everett, O'Callahan v. Parker-Milestone or Millstone in Military Justice?, 1969 DukE L.J. 853; Rice, O'Callahan v. Parker: Court-Martial Jurisdiction, "Service Connection," Confusion and the Serviceman, 51 Miltrary L. REv. 41 (1971); Note, O'Callahan v. Parker and Courl Martial Power after Termination of Active Duty, 70 Colum. L. REv. 1262 (1970). For a more complcte bibliography, see Relford v. Commandant, 401 U.S. 355, 356-57 n.1 (1971). 
We have concluded that the crime to be under military jurisdiction must be service connected .... In the present case petitioner was properly absent from his military base when he committed the crimes for which he is charged. There was no connection-not even the remotest one-between his military duties and the crime in question.8

The Supreme Court thus erected a standard of "service connection" to determine if a military court had jurisdiction to try cases involving servicemen.

\section{A. Service Connection and the Courts}

In its only amplification of $O^{\prime}$ Callahan, the Supreme Court held that crimes committed by servicemen against either person or property on a military installation were service connected. Speaking for a unanimous court in Relford v. Commandant, held the 1961 conviction of Isiah Relford, an Army corporal, for kidnapping and raping two women on the Fort Dix, N.J., military reservation. The court-martial, proceeding under UCMJ Articles 120 and 134, found that Relford had committed the crimes against the sister of a serviceman and the wife of an airman while the women were legally on military property.

In Relford, the Court identified on the basis of $O^{\prime}$ Callahan ${ }^{\text {to }}$ eleven indicia of non-connection with the service, but did not indicate how many of these ingredients are required to establish a lack of service connection, or even if the list is exhaustive. The factors are: (1) the serviceman's proper absence from the base; (2) the crime's commission away from the base; (3) its commission at a place not under military control; (4) its commission within our territorial limits and not in an occupied zone of a foreign country; (5) its commission in peacetimest and its being unrelated to authority stemming from the war power; (6)

48. 395 U.S. at $272-73$.

49. 401 U.S. 355 (1971), aff'g 409 F.2d 824 (10th Cir. 1969).

50. As Mr. Justice Douglas explained in O'Callahan:

In the present case petitioner was properly absent from his military base when he committed the crimes with which he is charged. There vas no conncetion-not even the remotest one-between his military duties and the crimes in question. The crimes were not committed on a military post or enclave; nor was the person whom he attacked performing any duties relating to the military. Mforeover, Hawail, the situs of the crime, is not an armed camp under military control, as are some of our far-flung outposts.

Finally, we deal with peacetime offenses, not with authority stemming from the war power. Civil courts were open. The offenses were committed within our territorial limits, not in the occupied zone of a foreign country. The offenses did not involve any question of the flouting of military authority, the security of a military post, or the integrity of military property.

395 U.S. at $273-74$.

51. Justice Blackmun assumed that despite the Vietnam conflict, Relford's offense $\propto$ curred in peacetime. 401 U.S. at 366. 
the absence of any connection between the defendant's military duties and the crime; (7) the victim's not being engaged in the performance of any duty relating to the military; (8) the presence and availability to a civilian court in which the case can be prosecuted; (9) the absence of any flouting of military authority; (10) the absence of any threat to a military post; and (11) the absence of any violation of military property. To these Justice Blackmun added "still another factor implicit in the others": (12) the offense's being among those traditionally prosecuted in civilian courts.52

O'Gallahan met all twelve conditions; hence, his offense was not service connected and he was beyond military jurisdiction. Relford's situation paralleled O'Callahan's in regard to points (4), (6), (8), (11), (12), and possibly (5) and (10). But Relford failed to satisfy conditions $(1),(2),(3),(7)$, and (10), and this was held sufficient to establish service connection. Relford's offense took place on base, one victim (a Post Exchange employee) was performing a military-related duty, and the crimes violated the post's security.

It can hardly be pretended that the facts which will establish or defeat service connection are very clear. At least one commentator has suggested that the failure to satisfy condition (7) is by itself sufficient to establish service connection. ${ }^{63}$ Although this suggestion renders the rest of the Relford analysis somewhat superfluous, it is not inconsistent with a number of pre-Relford decisions by the Court of Military Appeals. ${ }^{54}$

It should also be observed that the Court of Military Appeals has found instances of service connection outside the Relford situation when the defendant overtly uses his military status or rank to commit a crime. In United States $v$. Fryman, ${ }^{\text {b5 }}$ for example, the conviction of a Marine private who listed himself as an officer to establish credit in a civilian hotel was upheld on the ground that the defendant's false representation of his rank had been a necessary basis for his crime, thereby establishing that it was service connected.60

52. Id. at 365 .

53. Zillman, Recent Developments, 52 MiLITaRY L. REv. 169 (1971).

54. For example, that tribunal found service connection in an act of sodomy betwecn two servicemen in an off-base apartment, reasoning that any crime involving serviccmen as both perpetrator and victim damages the morale, reputation, and good order of the military. United States v. Lovejoy, 20 U.S.C.M.A. 18, 42 C.M.R. $210(1970)$.

For other cases where this theory was applied, see, e.g., United States v. Evcrson, 19 U.S.C.M.A. 70, 41 C.M.R. 70 (1969) (assault with a deadly weapon); United States v, Cook, 19 U.S.C.M.A. 13, 41 C.M.R. 13 (1969) (larceny); United States v. Comacho, 19 U.S.C.M.A. II, 41 C.M.R. I1 (1969) (housebreaking).

55. 19 U.S.C.M.A. 71, 41 C.M.R. 71 (1970).

56. Id. at 73 . 


\section{B. Service Connection and Indebtedness}

Although the notion of service connection is hardly very perspicuous, it would appear that under either Relford or a "military status" test (such as that in Fryman) most prosecutions for dishonorable failure to pay debt would not be service connected. ${ }^{5 \tau}$ Under Relford, only the first category of prosecutions (where there is a potentially detrimental effect on military discipline) would be arguably service connected. Since the victim would be a military person, critical condition (7) would not be satisfied; moreover the transaction would be likely to occur on post. The other two categories involve off-post transactions. ${ }^{\text {es }}$ In the second category, that concerning fraudulent transactions, the offense would fit all twelve points listed in Relford and so would clearly not be service connected. In the final category, only point (12)-the lack of a civilian counterpart-is present. This point is by far the weakest of the Relford criteria; it is nowhere suggested in Relford that it alone would be sufficient to establish service connection. No states permit criminal prosecutions and imprisonment for debt, absent fraud. Consequently, a serviceman could not suffer criminal consequences, in a state court action, for dishonorable failure to pay a debt. Yet this fact alone would not seem to permit the military to extend jurisdiction. Confronted with an analogous situation in Moylan $v$. Laird, a Rhode Island District Court held that a serviceman was entitled to benefit from the civilian sovereign's decision not to prosecute at all..$^{59}$

The "military status" test to establish jurisdiction will seldom be useful in indebtedness prosecutions. Since the crime is dishonorable failure to pay, and not, as in Fryman, the fraudulent use of a military status, it would not matter, under ordinary circumstances, whether the serviceman wore his uniform or told the merchant his rank at the time the obligation was incurred. Of course, if he used his military status to defraud the creditor, prosecution would be appropriate under separate UCMJ provisions. ${ }^{60}$

57. The jurisdictional dilemma posed by indebtedness has been recognized by two Air Force attorneys, who suggest administrative discharges as potential sanctions against the debtor. Dagle \& Lasseter, Straight Bankruptcy-the Wage Earners Plan and the MIilitary Debtor, 13 U.S.A.F. JAG L. REV. 137, 151 (1971).

58. Credit sales in post exchange facilities are limited to purchases of uniforms, use of gasoline credit cards and a few other items. 32 C.F.R. $\$ 544.10$ (1971).

59. 305 F. Supp. 551, 556 (D.R.I. 1969).

60. See, e.g., Article 121, 10 U.S.C. § 921 (1970) (larceny); Article 123a, 10 U.S.C. \& 9233 (1970) (worthless check); Article 132, 10 U.S.C. \& 932 (1970) (frauds against the government), and Article 134 specifications for impersonating an offeer or non-commissioned officer and the incorporation of all federal criminal statutes. 
Nor can it be said that "dishonor" alone makes debt prosecutions service connected. Prior to O'Callahan the argument was accepted that any deviant act by a serviceman discredits the military and can be prosecuted under Article 134. This theory was later rejected by the Court of Military Appeals, which ruled that an offense triable under Article 134 is not necessarily service connected merely because it may reflect discredit on the service. ${ }^{61}$ Jurisdiction has been denied to military courts in cases involving robbery and rape of civilians off post, ${ }^{03}$ burglary and larceny in a civilian community, ${ }^{03}$ and the off-base murder of a civilian. ${ }^{64}$ If raping the shopkeeper's daughter or stealing his goods in itself does not confer court-martial jurisdiction, it is difficult to make out a plausible case for it where the sole offense is not paying a bill.

\section{G. O'Callahan and the Misdemeanor}

It might be objected, in a final effort to save prosecutions for dishonorable failure to pay debt, that these prosecutions are somehow insulated from the effect of $O^{\prime}$ Callahan. The Court of Military Appeals has, indeed, recently attempted to limit the scope of the $O^{\prime} C a l l a h a n$ mandate by declaring it applicable only to serious crimes. In United States $\%$. Sharkey, ${ }^{65}$ a Marine was convicted for being drunk and disorderly in uniform in a public place while off duty. The court martial sentenced the enlisted man to four months confinement and forfeitures of $\$ 90$ per month for four months. The Court of Military Appeals rejected Sharkey's contention that his offense was not service connected:

It is important to read $O^{\prime}$ Callahan ... not by rote, but with an eye to the important constitutional protection which it sought to preserve to the soldier-accused. Thus, it specifically dealt with a civil-type offense, which if left to military jurisdiction, would offer "no way of saving servicemen and servicewomen in any case the benefit of indictment and of trial by jury." Here, how. ever, we are confronted with a petty military offense. ${ }^{68}$

Citing Supreme Court decisions that the constitutional guarantee of indictment and jury trial did not apply to civilian misdemeanors, the Court of Military Appeals concluded that O'Callahan applied only

\footnotetext{
61. United States v. Morriseau, 19 U.S.C.M.A. 17, 18, 41 C.M.R. 17, 18 (1969).

62. United States v. Borys, 18 U.S.C.M.A. 547, 40 C.M.R. 259 (1969).

63. United States v. Chandler, 18 U.S.C.M.A. 593, 40 C.M.R. 305 (1969).

64. United States v. Armstrong, 19 U.S.C.M.A. 5, 41 C.M.R. 5 (1969).

65. 19 U.S.C.M.A. 26, 41 C.M.R. 26 (1969). For a discussion of the impact of Sharkey, see Crawford, The Ambit of O'Callahan, 12 U.S.A.F. JAG L. REv. 100, 109 (1970).

66. 19 U.S.C.M.A. at 27, 41 C.M.R. at 27.
} 
to major crimes. It decided that any crime punishable by six months imprisonment or less was a petty crime and so not governed by the criteria for service connection laid down in $O^{\prime}$ Callahan, and that courtmartials could in such cases exercise their traditional jurisdiction.

Even if the Sharkey rationale is accepted, it would not apply to prosecutions for dishonorable failure to pay a debt, since Sharkey involved a less serious crime. The court seemed to base its holding entirely on a six month maximum prison term, which applies equally to the offense of being drunk and disorderly and to the indebtedness offense. The indebtedness offense, however, also permits a bad conduct discharge for the first conviction. ${ }^{67}$ This magnifies the seriousness of the crime, for the Army admits that a prejudicial discharge can be more serious than a felony conviction. In an official Army publication, military judges are told to instruct the jury that a bad conduct discharge is more severe than imprisonment at hard labor for one year. ${ }^{\text {cs }}$ Consequences of such a discharge include loss of retirement pay and other veteran's rights, and the severe restriction of opportunities for civilian employment, credit standing and entrance to licensed professions. ${ }^{69}$

Moreover, the Sharkey rationale itself is vulnerable to direct attack on several fronts. First, O'Callahan did not restrict the service connection criterion to felony-level cases. The Supreme Court cited defects in the system of military justice that apply to any court-martial regardless of the seriousness of the crime, such as the possibility of command influence, the existence of judges who are not constitutionally protected as to tenure and salary, and the lack of a requirement of a unanimous vote for a guilty verdict. 0 These characteristics result in military courts falling short of the kind of qualifications that the Constitution has set for fair trials of civilians in federal courts. ${ }^{\pi 1}$

67. The table of maximum punishments for military crimes is contained in Mravunt FOR Courts-Martial UNITED STATES $\$ 127 \mathrm{c}$ (rev. ed. 1969). The punishment listed in the text can be imposed either by a general court-martial, or by a special court-martial complying with the requirements of 10 U.S.C. $\$ 819$ (1970).

68. U.S. Dep't of Araty, Pairphlet No. 27-29, Millitary Junces' Guide $\$ 8.8$ (1969).

69. For a compilation of the service connected sanctions resulting from a prejudicial discharge, see Bednar, Discharge and Dismissal As Punishment In the Armed Forces, 16 MílTARX L. REv. 1 (1962).

It may be objected that as a matter of legal doctrine Sharkey stunds for the proposition that if a crime is not punishable by more than six months imprisonment it is ipso facto not "serious" and consequences other than imprisonment are irrelevant. The objection is unsound, for it involves an implausible interpretation of Sharkey, is inconsistent with the Army's general position on this matter (see note 68 supra), and is implausible on its face (since the consequences of a bad conduct discharge are indeed more serious than six months imprisonment).

70. 395 U.S. at 263-64.

71. Id. at 262-63, quoting from Toth v. Quarles, 350 US. 11, 17-18 (1955). 
Secondly, it is arguable that no military criminal offense can be considered a petty crime, since two previous convictions within three years make any court martial offense punishable by a bad conduct discharge. Chief Judge Quinn cited this provision in his concurrence in Sharkey to support his contention that no military crime can abstractly be described as minor. ${ }^{72}$

Finally, Sharkey would seem to rest on a mistaken interpretation of O'Callahan. In Sharkey, the Court of Military Appeals relied on a "functional" notion of jurisdiction. It interpreted $O^{\prime}$ Callahan to mean that military courts lacked jurisdiction because they did not provide constitutional guarantees which an accused must have, e.g., indictment by a grand jury and trial by jury. Reasoning inversely, the court concluded that if the guarantees were not required for minor crimes, the military courts would provide the same process as civilian courts. In that situation, military courts could retain jurisdiction.

But a recent habeas corpus case, Flemings $v$. Chafee, ${ }^{73}$ persuasively argues that $O^{\prime}$ Callahan dealt with jurisdiction in the classical legal sense, i.e. the power to judge a controversy. In Flemings, a 1944 courtmartial conviction of a sailor for off-base auto theft was overturned. Judge Weinstein ruled that $O^{\prime}$ Callahan should have retroactive application. ${ }^{74} \mathrm{He}$ held that "classic" jurisdiction was the central focus in O'Callahan; without a showing of service connection, military courts lack power over the subject matter. On the facts of this case, the court found that Flemings failed to meet only two points listed in $O^{\prime}$ Callahan and Relford for the determination of lack of service con* nection: he was absent without leave and the United States was involved in a global war. ${ }^{75}$ This was deemed insufficient for service connection. An interpretation relying on "classic" jurisdiction, then, makes the alternative procedure in civilian courts irrelevant to courtmartial jurisdiction. There is military jurisdiction only if the crime, be it major or minor, is service connected. ${ }^{76}$

72. 19 U.S.C.M.A. at 28, 41 C.M.R. at 28.

73. 330 F. Supp. 193 (E.D.N.Y. 1971).

74. The Court of Military Appeals found O'Callahan non-retroactive. Mercer v. Dillon, 19 U.S.C.M.A. 264, 41 C.M.R. 264 (1970). But see Judge Ferguson's dissent, 19 U.S.C.M.A. at 273, 41 C.M.R. at 273, employing a subject matter theory of jurisdiction. The Supreme Court expressly reserved the issue of retroactivity in Relford. 401 U.S. at 370 .

75. 330 F. Supp. at 198.

76. H.R. 579, 92d Cong., 1st Sess. (1971), would make the jurisdictional dilemma posed by $O^{\prime} C a l l a h a n$ moot. The bill would give federal district courts original jurisdiction for offenses punishable currently by Article 88 and Articles 107-134 UCMJ, if the offense were committed within the territorial limits of the United States. 


\section{Conclusion}

The military crime of dishonorable failure to pay a just debt raises serious policy and jurisdictional problems. Prosecution serves no permissible military goal that cannot be achieved through other means, and operates, in its breadth, to disadvantage the non-fraudulent military debtor. The military currently performs a service for creditors quite beyond that performed by other government-employer agencies. Even if it is deemed wise for the military to involve itself in facilitating the task of creditors, the crime of dishonorable failure to pay a just debt is a poor, because ineffective, policy. Finally, it appears that courts-martial lack jurisdiction to entertain prosecutions for debt. Now, when much is made of the prospect of an all-volunteer army, it would be both timely and just to eliminate from the military experience this pernicious anachronism. 